\title{
New species of Rogmocrypta Simon, 1900 from New Caledonia, with remarks on relationships and distribution (Araneae, Salticidae)
}

\author{
Barbara M. Patoleta', Joanna Gardzińska', Marek Żabka' \\ I Siedlce University of Natural Sciences and Humanities, Faculty of Natural Science, Department of Zoology, \\ Prusa 12, 08-110 Siedlce, Poland \\ Corresponding author: Barbara M. Patoleta (patoleta@uph.edu.pl)
}

Academic editor: J. Miller | Received 24 April 2017 | Accepted 19 July 2017 | Published 14 September 2017

http://zoobank.org/C4C41E68-1447-4528-AC52-B4E2B9104CC4

Citation: Patoleta BM, Gardzińska J, Żabka M (2017) New species of Rogmocrypta Simon, 1900 from New Caledonia, with remarks on relationships and distribution (Araneae, Salticidae). ZooKeys 697: 73-86. https://doi.org/10.3897/ zookeys.697.13381

\begin{abstract}

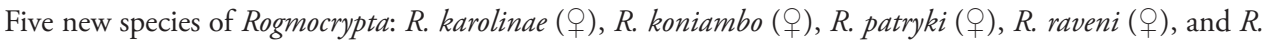
rollardae (P) are diagnosed, described, and illustrated. The definition of the genus is ammended and its distribution and relationships are discussed.
\end{abstract}

\section{Keywords}

distribution modelling, jumping spiders, Pacific Islands

\section{Introduction}

The fauna of New Caledonia is often discussed in terms of Gondwanan heritage. Indeed, the island group was separated from Gondwana some 85 MYA, but later experienced multiple subductions and submergences (Cluzel et al. 2012) and, in fact it only emerged in post-Eocene (37 MYA). Consequently, New Caledonian biota, fauna, and flora should not be discussed in terms of direct Gondwanan heritage, but rather as the result of local radiations and colonisation from other sources (Keast and Miller 1996, Grandcolas et al. 2008, Heads 2008, 2010, 2014). The phenomenon of local radiation is also known for several salticid genera such as Corambis Simon, 1901, Penionomus Simon, 1903 and Rhondes Simon, 1901 (Maddison et al. 2008); all are part of the Aus- 
tralasian Astioida clade and derived from Australian ancestors between 9 and 20 MYA (Bodner and Maddison 2012). The genus Rogmocrypta (here) with seven nominal species is also the case of radiation in situ.

Our initial aim is to present a complete revision of the genus; however, the lack of type material for $R$. nigella Simon, 1900 and $R$. puta Simon, 1900 limited our goals.

\section{Materials and methods}

The material was obtained from the following collections:

MNHN Museum National d'Histoire Naturelle, Paris, France

QM Queensland Museum, Brisbane, Australia.

The examination specimen methods were as described by Żabka (1991). The drawings were made using a grid system. The photographs were taken with Nikon D5200 camera and Nikon SMZ1000 stereomicroscope, and were digitally processed with ZoomBrowser and HeliconFocus software. The dissected epigynes were digested in $10 \% \mathrm{KOH}$ and studied under compound microscope. The actual and predicted distributional maps were generated with DIVA-GIS bio-climatic software using BIOCLIM application (Nix, 1986; Busby, 1991). Our model has been produced with 14 field records and met the requirements for the software (at least 5-10 records; Hernandez et. al. 2006). The following environmental variables were used in the analysis: annual mean temperature, mean monthly temperature range, isothermality, temperature seasonality, max temperature of warmest month, min temperature of coldest month, temperature annual range, mean temperature of wettest quarter, mean temperature of driest quarter, mean temperature of warmest quarter, mean temperature of coldest quarter, annual precipitation, precipitation of wettest month, precipitation of driest month, precipitation seasonality, precipitation of wettest quarter, precipitation of driest quarter, precipitation of warmest quarter, precipitation of coldest quarter.

\section{Abbreviations used in the text and figure legends are:}

$\begin{array}{llll}\text { AEW } & \text { anterior eye width, } & \text { eo endites outgrowth, } \\ \text { AME anterior medial eyes, } & \text { fd } & \text { fertilisation duct, } \\ \text { AL abdomen length, } & \text { L } & \text { leg, } \\ \text { AW abdomen width, } & \text { PEW posterior eye width, } \\ \text { cd copulatory duct, } & \text { PLE posterior lateral eyes, } \\ \text { CH cephalothorax height, } & \text { PME } & \text { posterior medial eyes, } \\ \text { CL cephalothorax length, } & \text { rta } & \text { retrolateral tibial apophysis, } \\ \text { co copulatory opening, } & \mathbf{s} & \text { spermatheca, } \\ \text { CW cephalothorax width, } & \mathbf{t} & \text { tegulum, } \\ \text { EFL eye field length, } & \mathbf{t r} & \text { transverse ridge. } \\ \text { e } & \text { embolus, } & & \end{array}$




\section{Taxonomy}

\section{Genus Rogmocrypta Simon, 1900}

Rogmocrypta Simon, 1900: 387; 1901: 389, 445-446; Maddison et al. 2008: 52-55; Maddison 2015: 277.

Type species. $R$. elegans $($ Simon 1885) $=$ Chalcoscirtus elegans Simon 1885, originally designated by Simon (1900).

Diagnosis. Differs from related genera by tiny or small body size. Unlike in Lystrocteissa (Patoleta and Gardzińska 2013, figs 9-15) the habitus is not ant-mimic (Figs 1, 7, 10, 16, 28) and much more compact than in Corambis (Szüts 2002, figs 1, 10-12). Male palpal embolus ${ }^{1}$ is sabre-like (Fig. 5) and shorter than in Penionomus (Żabka 1988, fig. 114) and in some species of Rhondes (Patoleta 2016, figs 9-14). Tegulum without lobe (more or less marked in relatives). Seminal duct not meandering, tibial apophysis short (Fig. 6). Unlike in Rhondes (Patoleta 2016, figs 22-27). Epigyne with no central pocket (Figs 8, 14, 20, 25, 34). Copulatory ducts much shorter than in Penionomus (Żabka 1988, fig. 118) and not twisted (Figs 9, 15, 21, 27, 36, 43). Accessory glands not distinctive - unlike in Corambis (Szüts 2002, figs 4, 17) where they are long.

Description. Cephalothorax medium-high, longer than broad and widest at the level of coxae II; fovea in distinct depression, posterior slope steep, starting behind fovea, eye field wider than long, trapezoid (PLE<ALE). Eyes in three rows, the first row straight. Chelicerae with two promarginal teeth, retromarginal tooth 4-6-cuspidate (Figs 19, 33, 41). Endites slender and divergent, in male with lateral outgrowth (Fig. 3). Labium wider than long. Sternum longer than wide. Abdomen ovoid, longer than wide. Spinnerets short. Legs moderately long and thin. Leg formula: I-IV-II-III. Male palpal organ simple: cymbium unmodified, tegulum longer than wide, ovoid, with no lobes, embolus curved, rather thin, retrolateral tibial apophysis single (Fig. 6). Epigyne copulatory openings located close to each other (Figs 21, 27, 43) or distinctly separated (Figs 9, 15, 36), sometimes strongly sclerotised (Figs 25-27). Copulatory ducts narrow. Spermathecae C-shaped (Figs 9, 15, 36) or semicircular (Figs 21, 27, 43).

Distribution. According to WSC (2017) three species of Rogmocrypta are listed from New Caledonia ( $R$. elegans), Philippines ( $R$. nigella Simon, 1900) and Singapore (R. puta Simon, 1900). However, two latter are poorly known, their bioclimatic distributional predictions (Fig. 45) do not match Rogmocrypta-pattern and they probably are not congeneric. Additionally, the five species described here seem to confirm New Caledonia as the diversity and radiation centre.

Biology. The species treated here are litter dweller in humid forests.

Remarks. According to recent molecular studies (Maddison et al. 2008, Maddison 2015), Rogmocrypta belongs to Viciriini tribe within the Australasian Astioida clade and is closely related to other New Caledonian genera such as Trite Simon, 1885,

<? The diagnosis is handicapped by the lack of males for most species

1 The diagnosis is handicapped by the lack of males for most species 
Penionomus Simon, 1903 and Lystrocteissa Simon, 1884. However, the analysis of male genitalia here and in Maddison et al (2008: fig. 3) raises some doubts about congeneric status of $R$. elegans (we dealt with the type) and cf. Rogmocrypta sp. in Maddison et al. (2008): both show important differences in embolus structure and tegular lobe, which is missing in $R$. elegans. To clarify the relationships of Rogmocrypta it is necessary to perform molecular tests for all species ever listed in the genus. At this stage any reference to other New Caledonian genera as possible relatives can only be provisional.

\section{Rogmocrypta elegans (Simon, 1885)}

Figures 1-9, 44

Chalcoscirtus elegans Simon, 1885: 90.

Rogmocrypta elegans: Simon 1901: 445-446, figs 506D-E; Prószyński 1984: 123-124.

Material. $1 \overbrace{}^{\Uparrow}$ holotype, 19 paratype, New Caledonia: Nouméa, MNHN Paris, nr 7527.

Diagnosis. Males abdomen with two whitish stripes (Figs 1-2), embolus curved, arising from antero-prolateral part of tegulum (Fig. 5), retrolateral tibial apophysis short and conical (Fig. 6). Epigyne copulatory openings oriented towards each other, more separated than in R. koniambo sp. n.

Distribution. Known only from the type locality (Fig. 44).

Remark. This is the only known and illustrated species of Rogmocrypta (Prószyński 1984), and it is used here for comparative purposes.

\section{Rogmocrypta karolinae sp. $\mathrm{n}$.} http://zoobank.org/184FCC48-B4F4-4034-B68B-68B2F3BF1D8A Figures 10-15, 44

Material. 1 ㅇ holotype, New Caledonia: Mandjélia (164² $\left.32^{\prime} \mathrm{E}, 20^{\circ} 24^{\prime} \mathrm{S}\right), 600 \mathrm{~m}$ elev., rainforest, pitfalls, October 1992-17 February 1993, Raven R, Guillbert E, QM S44894;

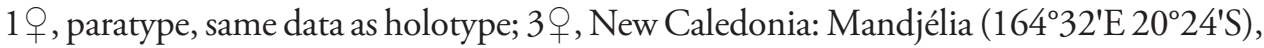
pitfalls, 13 May-October 1992, Raven R, Guillbert E, Ingram G, QM S37722.

Etymology. For Karolina, daughter of Joanna Gardzińska.

Diagnosis. Cephalothorax and abdomen with distinctive patches of white scales (Figs 10-11). Copulatory openings closer to each other than in $R$. elegans (Fig. 15). Spermathecae horizontal (Figs 14-15).

Description. Female holotype. Cephalothorax brown with darker cephalic part, with patches of scales (Fig. 10). Abdomen greyish brown, with three pairs of patches covered with white scales. Spinnerets whitish. Chelicerae with single retromargin 5-cuspidate tooth. Clypeus narrow (17\% of AME diameter), covered with sparse white hairs. Labium and endites brown with lighter chewing margins. Sternum and venter greyish brown. Legs light brown, tibiae and metatarsi with darker bands (Fig. 12), 

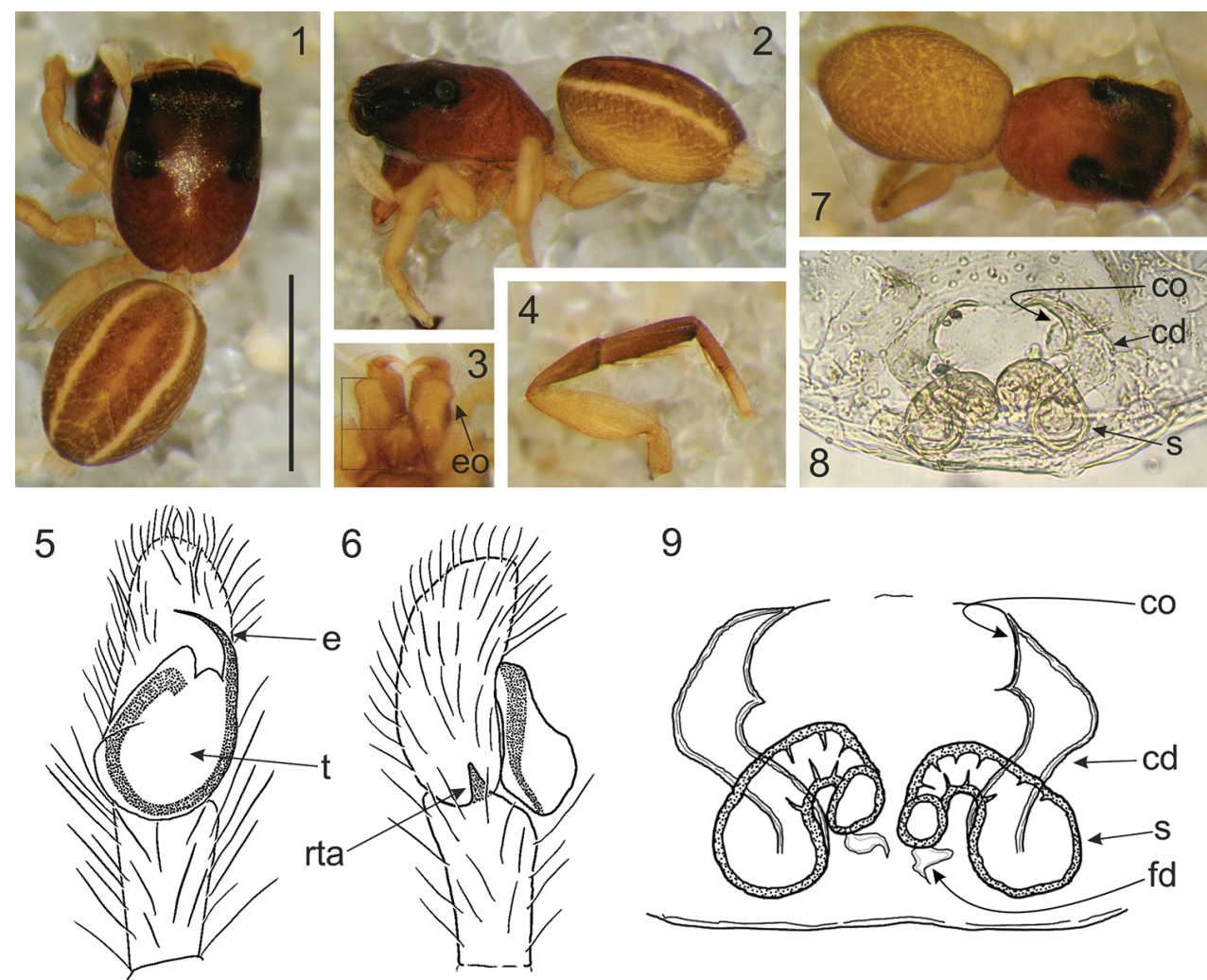

Figures I-9. Rogmocrypta elegans. I-6 Male (holotype) I Dorsal view 2 Lateral view 3 Endites and labium 4 First leg 5 Right palp ventrally 6 Same, retrolaterally 7-9 Female (paratype) 7 Dorsal view 8-9 Vulva. Abbreviations: cd: copulatory duct, co: copulatory opening, e: embolus, eo: endites outgrowth, fd: fertilisation duct, rta: retrolateral tibial apophysis, s: spermatheca, t: tegulum. Scale bar: $1 \mathrm{~mm}$.

metatarsi and patellae covered by white scales. Epigyne copulatory openings oriented towards each other, copulatory ducts sinuous, spermathecae C-shaped, close to each other (Fig. 15). Dimensions. CL 1.23, CW 0.95, CH 0.54, EFL 0.55, AEW 0.97, PEW 0.85, AL 1.15, AW 1.05, LI: 3.42, LII: 1.99, LIII: 1.70, LIV: 2.61.

Male unknown.

Distribution. Known from type locality only (Fig. 44).

\section{Rogmocrypta koniambo sp. $\mathbf{n}$.}

http://zoobank.org/FF2E8207-FCA3-4854-8F15-BABDE1AE13AF

Figures 16-21, 44

Material. 1 ㅇ holotype, New Caledonia: Mt. Koniambo (16447'11"E, 2059'42"S), 700m elev., forêt seche/rub, A\&S Tillier, 25 March 1987, MNHN.

Etymology. The name refers to the type locality. 

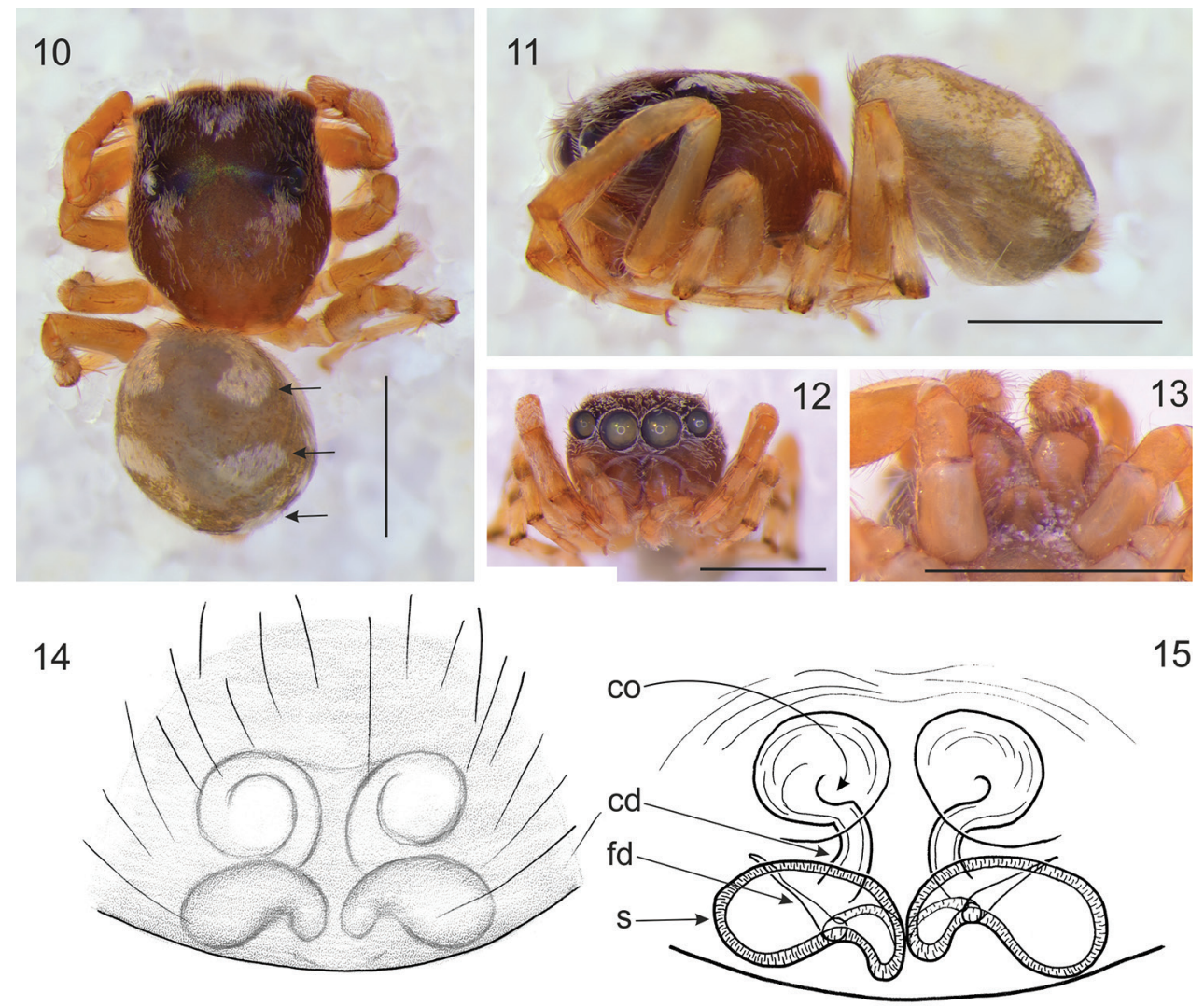

15

Figures I0-15. Rogmocrypta karolinae sp. n. (female holotype). I0 Dorsal view (arrows indicate patches of white scales being distinctive diagnostic characters) I I Lateral view I 2 Frontal view $\mathbf{3}$ Endites and labium 14 Epigyna I5 Vulva. Abbreviations: cd: copulatory duct, co: copulatory opening, fd: fertilisation duct, s: spermatheca. Scale bars: $1 \mathrm{~mm}($ I 0-| 3); $1.20 \mathrm{~mm}(\mathbf{I 4}) ; 0.08 \mathrm{~mm}(\mathbf{I 5})$.

Diagnosis. In comparison to previous species copulatory openings closer to each other and located just in front of spermathecae.

Description. Female holotype (in bad condition). Cephalothorax brown with darker cephalic part, covered with sparse white scales. Foveal depression well marked (Fig. 16). Abdomen ovoid, pale, covered with sparse white scales. Spinnerets whitish. Palps and legs II and III greyish brown. Other legs missing. Chelicerae short, brown, retromarginal tooth 6-cuspidate (Fig. 19). Labium brown, endites light brown with whitish chewing margins. Venter whitish. Epigyne copulatory ducts and spermathecae semicircular, the latter almost horizontal (Fig. 21). Dimensions: CL 1.06, CW 0.77, CH 0.42, EFL 0.51, AEW 0.80, PEW 0.65, AL 0.93, AW 0.74, LI and LII missing, LIII: 1.58, LIV: 1.72.

Male unknown.

Distribution. Known from type locality only (Fig. 44). 

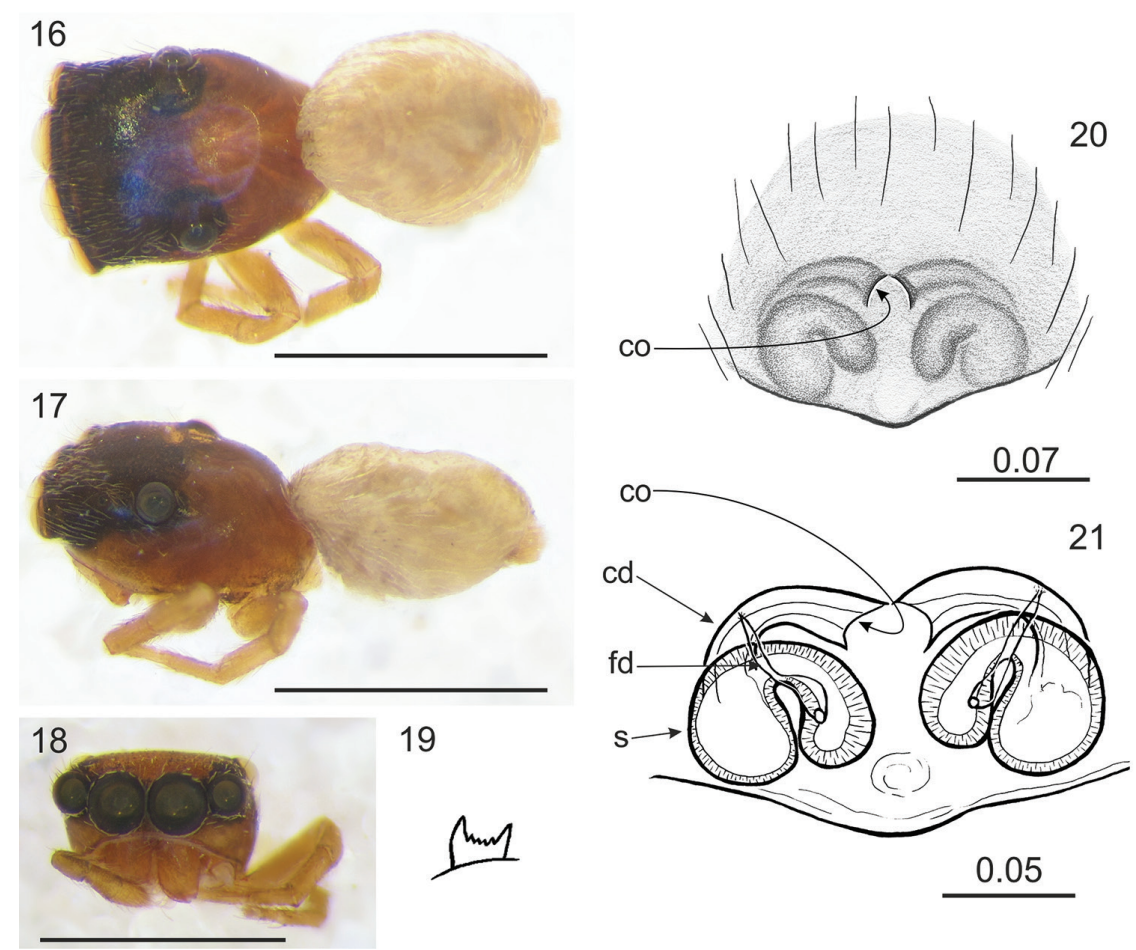

Figures 16-21. Rogmocrypta koniambo sp. n. (female holotype). 16 Dorsal view 17 Lateral view 18 Frontal view 19 Retromarginal tooth 20 Epigyna 21 Vulva. Abbreviations: cd: copulatory duct, co: copulatory opening, fd: fertilisation duct, s: spermatheca. Scale bars: $1 \mathrm{~mm}$ ( I 6-I 8); $0.07 \mathrm{~mm}$ (20); $0.05 \mathrm{~mm}$ (2 I).

\section{Rogmocrypta patryki sp. n.}

http://zoobank.org/550946C1-6C62-417A-815C-68E1E0D0C870

Figures 22-27, 44

Material. $1+$ holotype, New Caledonia: Mt. Oua Tilou (16451'28"E, 2051'57"S), arête S, 510 m elev., foret sèche, berlesate, st. 198a, 19 October 1988, A\&S Tillier, Chazeau J, MNHN; 19 paratype same data as holotype; 19 , New Caledonia: Mt. Panié, 450-950m, 14 May 1984, Monteith G, Cook D, QM S35668; 1 9 , New Caledonia: Mt. Panié summit, 1628 m elev., 15 May 1984, Monteith G, Cook D, QM S35665; 2 ㅇ, 1 juv. New Caledonia: Mt. Oua Tilou (164²51'28"E, 2051'57"S), arête S, 510m elev., foret sèche, berlese, st. 198a, 19 October 1988, A\&S Tillier, Chazeau J, MNHN.

Etymology. For Patryk Patoleta, Barbara Patoleta's son.

Diagnosis. Abdomen with lighter chevrons and distinctive white patches (Fig. 23). Copulatory openings close to each other, orientated posteriorly, and located well anteriorly to spermathecae (Figs 25-27).

Description. Female holotype. Cephalothorax brown, with darker eye field and foveal depression (Fig. 22). Abdomen greyish brown, with distinctive pattern as in Fig. 23. Spinnerets light brown. Cheliceral retromarginal tooth 5-cuspidate. Clypeus 

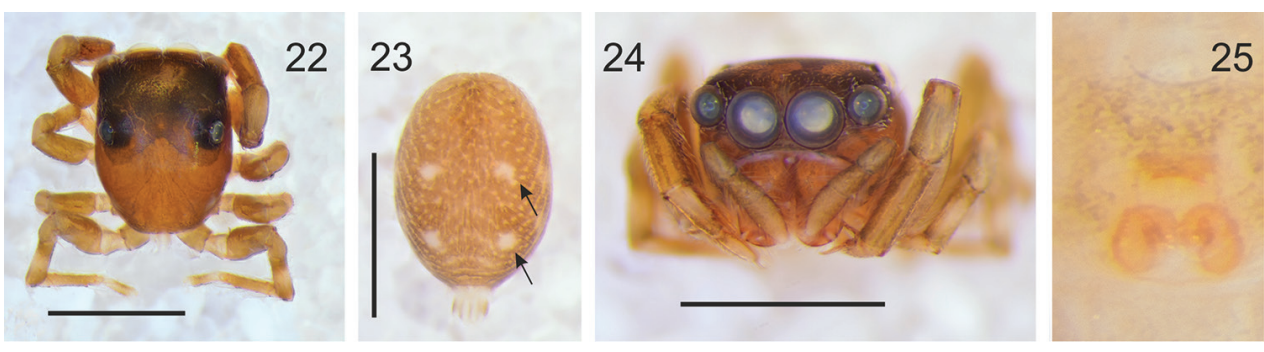

26

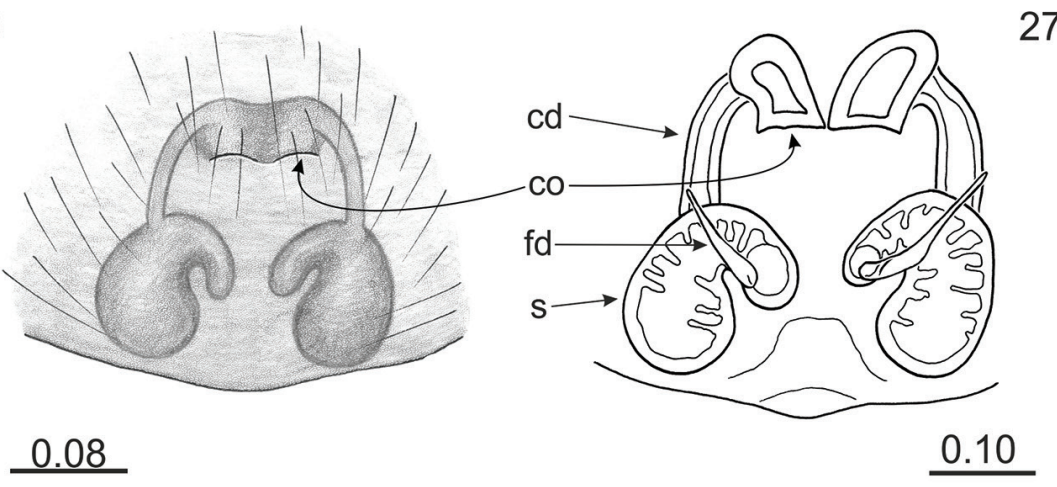

Figures 22-27. Rogmocrypta patryki sp. n. (female holotype). 22 Cephalothorax, dorsal view 23 Abdomen, dorsal view (arrows indicate white patches being distinctive diagnostic characters) 24 Frontal view 25-26 Epigyna 27 Vulva. Abbreviations: cd: copulatory duct, co: copulatory opening, fd: fertilisation duct, s: spermatheca. Scale bars: $1 \mathrm{~mm}(\mathbf{2 2 - 2 4 )} 0.08 \mathrm{~mm}$ (26); $0.10 \mathrm{~mm}(\mathbf{2 7})$.

brown, much narrower (6\%) than AME diameter. Labium and endites light brown. Sternum brown. Venter whitish, with brownish spots. Legs brown, tibiae and metatarsi with darker bands (Figs 22, 24). Epigyne copulatory ducts and spermathecae semicircular, the latter in diagonal position (Figs 26-27). Dimensions. CL 1.40, CW 1.05, CH 0.65, EFL 0.63, AEW 1.00, PEW 0.95, AL 1.53, AW 1.08, LI: 3.06, LII: 2.42, LIII: 2.56 , LIV: 3.37 .

Male unknown.

Distribution. Known from Mt. Panié and Mt. Oua Tilou in New Caledonia (Fig. 44).

\section{Rogmocrypta raveni sp. $\mathrm{n}$.}

http://zoobank.org/8A020BFF-2D8F-4D8F-9EDA-510F8FB8E22C

Figures 28-36, 44

Material. 1 ㅇ holotype, New Caledonia: Mt. Panié (20³5'S, $\left.164^{\circ} 45^{\prime} \mathrm{E}\right), 400 \mathrm{~m}$ elev., pitfalls, October 1992 - February 1993, Raven R, Guillbert E, Ingram G, QM S35759; $2+9$ paratypes, same data as holotype.

Etymology. For Dr Robert Raven (Queensland Museum, Brisbane), distinguished Australian arachnologist and collector of the material studied. 

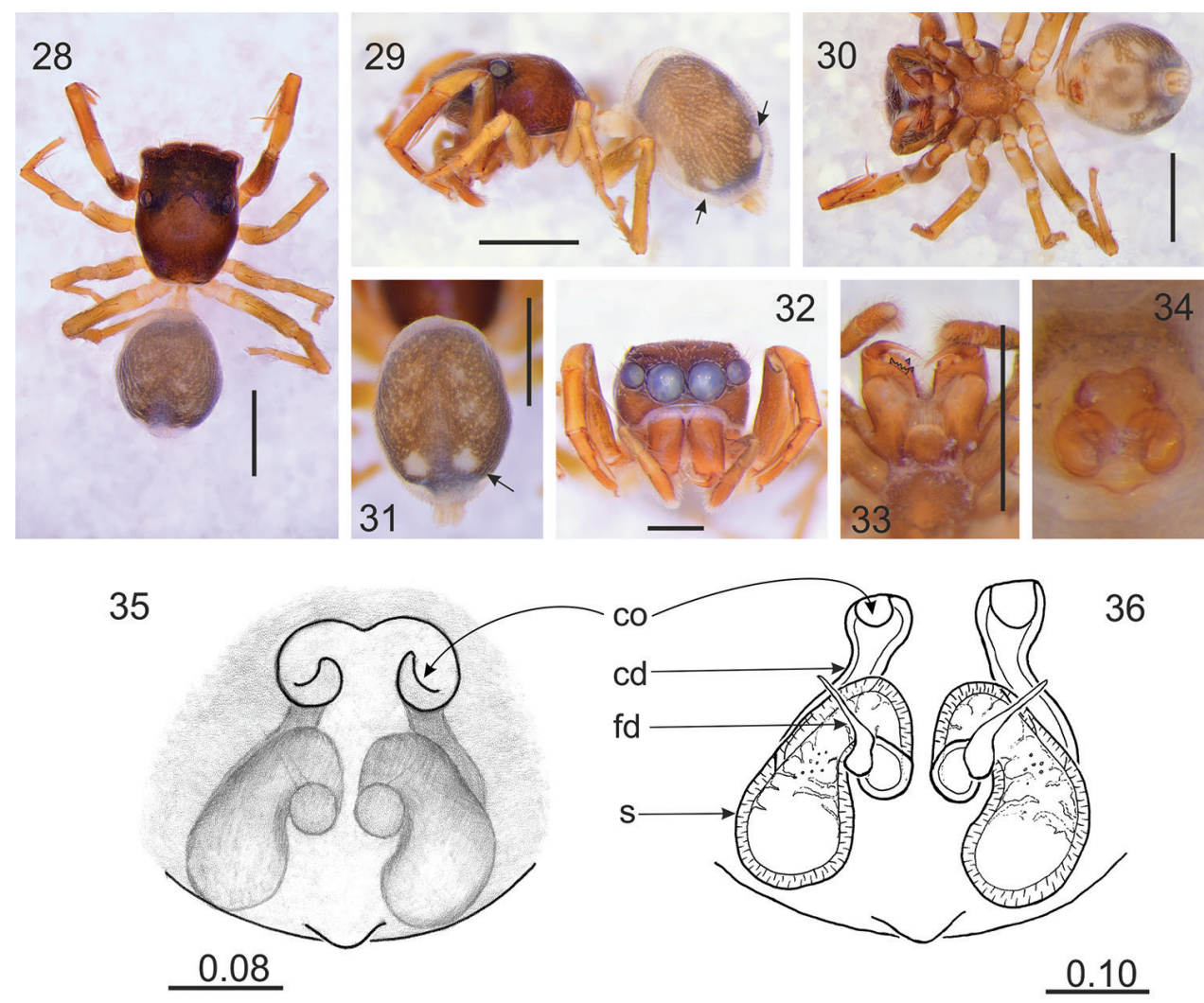

Figures 28-36. Rogmocrypta raveni sp. n. (female holotype). 28 Dorsal view 29 Lateral view $\mathbf{3 0}$ Ventral view 31 Abdomen dorsal view 32 Frontal view 33 Endites and labium 34-35 Epigyna 36 Vulva. (arrows in Figs 29 $\& \mathbf{3} \mathbf{I}$ indicate white spots being distinctive diagnostic characters). Abbreviations: cd: copulatory duct, co: copulatory opening, fd: fertilisation duct, s: spermatheca. Scale bars: $1 \mathrm{~mm}$ (28-33); $0.08 \mathrm{~mm}$ (35); $0.10 \mathrm{~mm}$ (36).

Diagnosis. Abdomen with white dorsal and ventral spots (Figs 29-31). Copulatory openings oriented anteriorly (Fig. 35), copulatory ducts undulating (Fig. 36).

Description. Female holotype. Cephalothorax brown, with darker cephalic part, covered by sparse whitish scales. Foveal depression well marked (Fig. 28). Abdomen ovoid, grey brown with lighter pattern as in Fig. 31, covered with sparse brown hairs. Anterior spinnerets light brown, posterior ones whitish. Palps brown. Legs I brown, others lighter. Chelicerae brown, retromarginal tooth 5-cuspidate (Fig. 33). Labium and endites light brown, with lighter chewing margins. Sternum brown. Venter with white and greyish brown pattern (Fig. 30). Epigyne with copulatory openings well separated from each other and from spermathecae, the last in diagonal position, C-shaped (Figs 34-36). Dimensions. CL 1.30, CW 1.03, CH 0.60, EFL 0.60, AEW 1.00, PEW 0.95, AL 1.50, AW 1.07, LI: 4.05, LII: 2.85, LIII: 2.70, LIV: 3.15.

Male unknown.

Distribution. Known from type locality only (Fig. 44). 

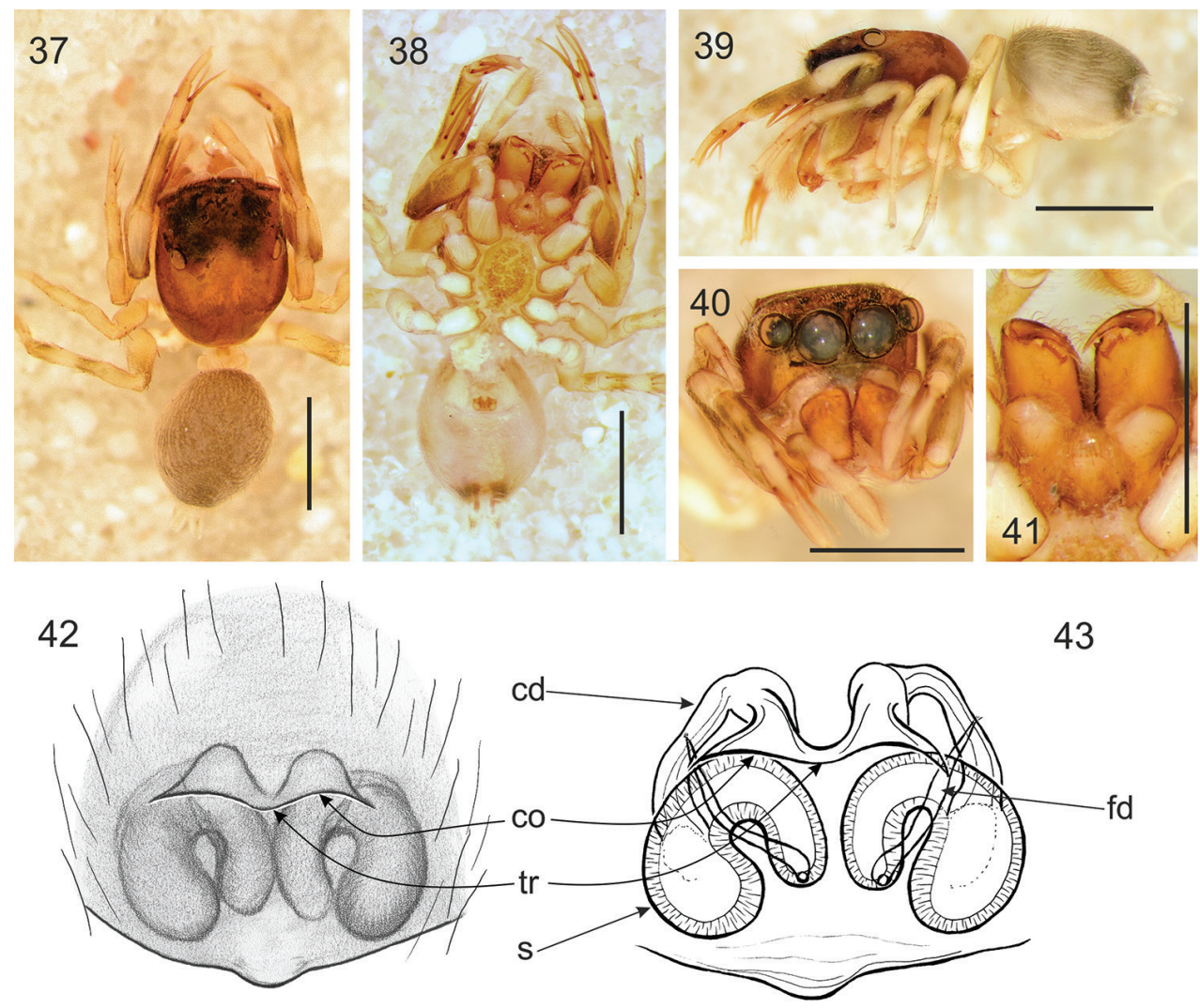

$\underline{0.04}$

$\underline{0.05}$

Figures 37-43. Rogmocrypta rollardae sp. n. (female holotype). 37 Dorsal view 38 Ventral view 39 Lateral view 40 Frontal view 41 Endites and labium 42 Epigyna $\mathbf{4 3}$ Vulva. Abbreviations: cd: copulatory duct, co: copulatory opening, fd: fertilisation duct, s: spermatheca, tr: transverse ridge. Scale bars: $1 \mathrm{~mm}(\mathbf{3 7 - 4 1})$; $0.04 \mathrm{~mm}$ (42); $0.05 \mathrm{~mm}$ (43).

\section{Rogmocrypta rollardae sp. $\mathbf{n}$.}

http://zoobank.org/94431F06-A47C-4CBA-936B-DE925E98083D

Figures 37-44

Material. $1 q$ holotype, New Caledonia: Mandjélia (20 $\left.24^{\prime} \mathrm{S}, 164^{\circ} 32^{\prime} \mathrm{E}\right), 650 \mathrm{~m}$ elev., rainforest, litter, berlesate, 12 May 1984, Monteith G, Cook D, QM S35648; 2 paratypes, New Caledonia: $4 \mathrm{~km} \mathrm{~N}$ of Col d'Amieu $\left(21^{\circ} 19^{\prime} 48^{\prime \prime S}, 165^{\circ} 30^{\prime} \mathrm{E}\right)$, rainforest, litter, 300 m elev., berlesate No 640, 8 May 1984, Monteith G, Cook D, QM; 1 , New Caledonia: Mandjélia (202'ㄴ, $\left.164^{\circ} 32^{\prime} \mathrm{E}\right), 700 \mathrm{~m}$ elev., rainforest, litter, berlesate nr 648, 12 May 1984, Monteith G, Cook D, QM S35651; 1 ㅇ New Caledonia: Dent de St. Vincent $\left(166^{\circ} 13^{\prime} 02^{\prime \prime} \mathrm{E}, 21^{\circ} 52^{\prime} 12^{\prime \prime} \mathrm{S}\right)$, arete S, $1150 \mathrm{~m}$ elev., forêt-magius haut humide, berlese, 6 August 1987, A\&S Tillier, Bonnet, Letocart, MNHN. 


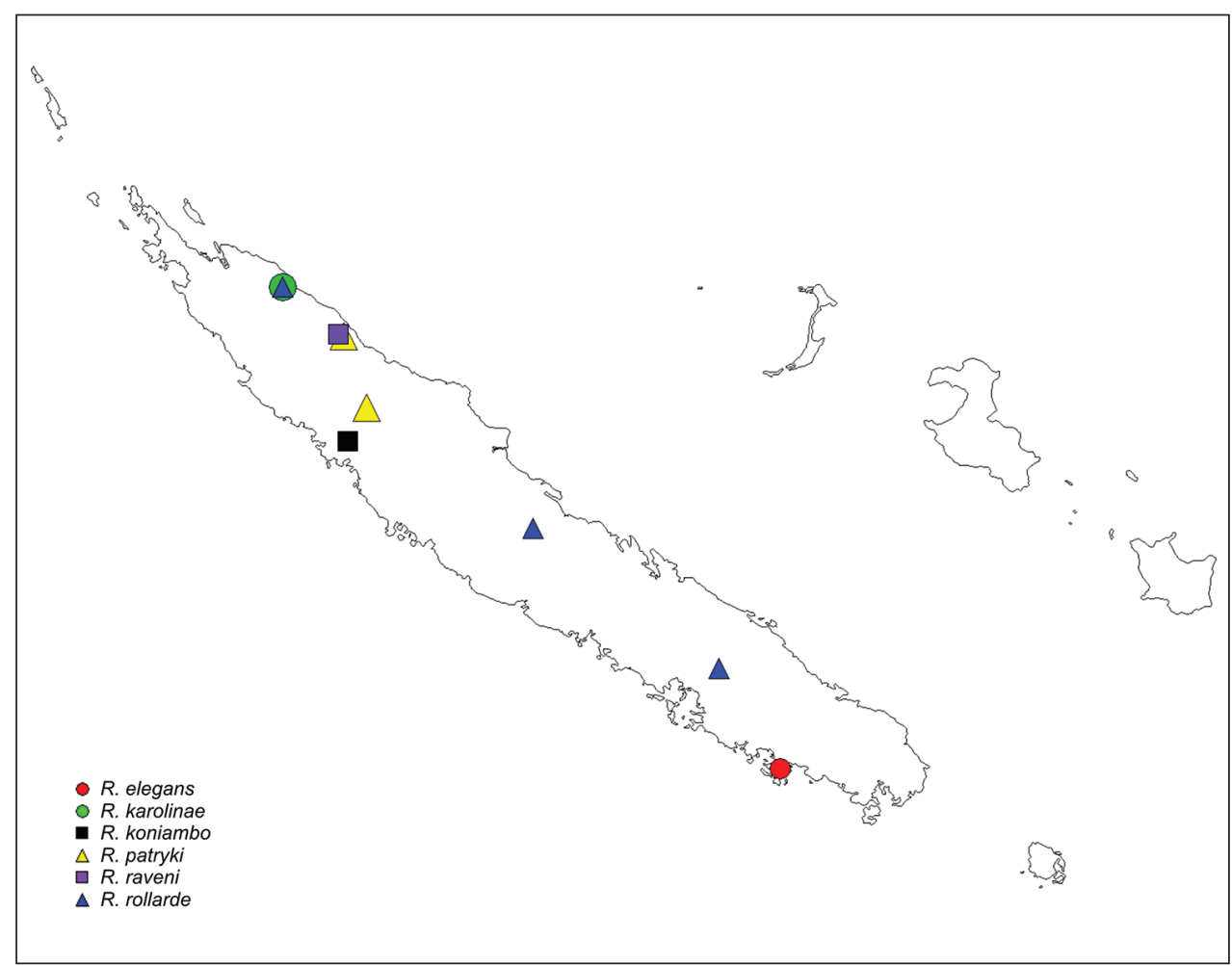

Figure 44. Distribution records of Rogmocrypta: $R$. elegans (red circle), $R$. karolinae (green circle), $R$. koniambo (black square), $R$. patryki (yellow triangle), $R$. raveni (purple square), $R$. rollardae (blue triangle).

Etymology. For Dr. Christine Rollard (MNHN, Paris), distinguished French arachnologist.

Diagnosis. Copulatory openings close to spermathecae, oriented posteriorly and joined, forming kind of transverse ridge (Figs 42-43).

Description. Female holotype. Cephalothorax brown, covered with sparse white scales and brown hairs. Foveal depression well marked. Abdomen brownish, with lighter chevrons (Fig. 37). Anterior spinnerets light brown, posterior ones whitish. Palps and legs brownish with darker bands. Chelicerae brown, retromarginal tooth 6-cuspidate. Labium and endites light brown with lighter chewing margins. Sternum grey brown. Venter with white and grey brown pattern (Fig. 38). Epigyne with copulatory openings strongly sclerotized and close to each other (Figs 42-43). Copulatory ducts and spermathecae semicircular, the latter in diagonal position (Fig 43). Dimensions. CL 1.82, CW 1.32, CH 0.83, EFL 0.78, AEW 1.22, PEW 1.09, AL 1.97, AW 1.45, LI: 5.24, LII: 3.64, LIII: 4.34, LIV: 4.92.

Male unknown.

Distribution. Known from Mandjélia, Col d'Amieu and Dent de St. Vincent in New Caledonia (Fig. 44). 


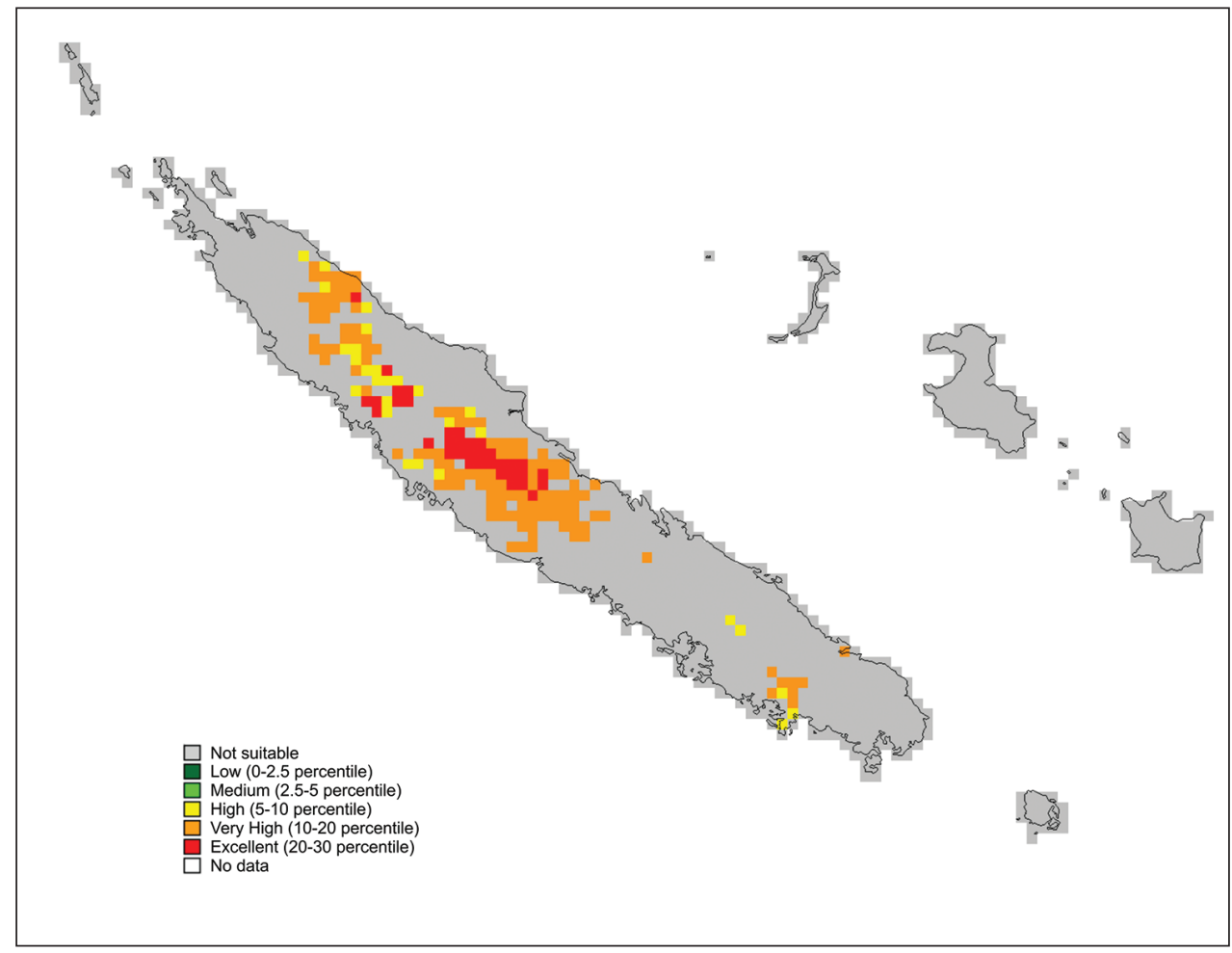

Figure 45. Predicted distribution of Rogmocrypta (14 records).

\section{Acknowledgments}

Dr Christine Rollard (Museum National d'Histoire Naturelle, Paris) and Dr. Robert Raven (Queensland Museum, Brismane) provided specimens for study and generous help during our visits (BP \& MŻ) to their institutions. Prof. Wayne Maddison (Vancouver, Canada) and Dr. Dmitri Logunov (Manchester, United Kingdom) reviewed the manuscript and provided critical comments and suggestions. The research is part of the project 18/91/S conducted in our university.

\section{References}

Bodner MR, Maddison WP (2012) The biogeography and age of salticid spider radiations (Araneae: Salticidae). Molecular Phylogenetics and Evolution 65: 213-240. https://doi. org/10.1016/j.ympev.2012.06.005 
Busby JR (1991) BIOCLIM - a bioclimate analysis and prediction system. In: Margules CR, Austin MP (Eds) Nature conservation: cost effective biological surveys and data analysis. CSIRO, 64-68.

Cluzel D, Maurizot P, Collot J, Sevin B (2012) An outline of the Geology of New Caledonia; from Permian-Mesozoic Southeast Gondwanaland active margin to Cenozoic obduction and supergene evolution. Episodes 35(1): 72-86.

Grandcolas P, Murienne J, Robillard T, Desutter-Grandcolas L, Jourdan H, Guilbert E, Deharveng L (2008) New Caledonia: a very old Darwinian island? Philosophical Transactions of the Royal Society B: Biological Sciences 363: 3309-3317. https://doi.org/10.1098/rstb.2008.0122

Heads M (2008) Panbiogeography of New Caledonia, southwest Pacific: basal angiosperms on basement terranes, ultramafic endemics inherited from volcanic arcs, and old taxa endemic to young islands. Journal of Biogeography 35: 2153-2175. https://doi.org/10.1111/j.13652699.2008.01977.x

Heads M (2010) The endemic plant families and the palms of New Caledonia: a biogeographical analysis. Journal of Biogeography 37: 1239-1250. https://doi.org/10.1111/j.13652699.2010.02292.x

Heads M (2014) Biogeography of Australasia: A Molecular Analysis. Cambridge University Press, Cambridge, 493 pp. https://doi.org/10.1017/CBO9781139644464

Hernandez PA, Graham CH, Master LL, Albert DL (2006) The effect of sample size and species characteristics on performance of different species distribution modeling methods. Ecography 29: 773-785. https://doi.org/10.1111/j.0906-7590.2006.04700.x

Keast A, Miller SE (1996) The origin and evolution of Pacific island biotas, New Guinea to Eastern Polynesia: Patterns and processes. SPB Academic Publishing Amsterdam, Holland, $531 \mathrm{pp}$.

Maddison WP (2015) A phylogenetic classification of jumping spiders (Araneae: Salticidae). Journal of Arachnology 43(3): 231-292. https://doi.org/10.1636/arac-43-03-231-292

Maddison WP, Bodner MR, Needham KM (2008) Salticid spider phylogeny revisited, with the discovery of a large Australasian clade (Araneae: Salticidae). Zootaxa 1893: 49-64.

Nix H (1986) A biogeographic analysis of Australian elapid snakes. In: Longmore R (Ed.) Atlas of elapid snakes of Australia. Bureau of Flora and Fauna, Canberra, 4-15.

Patoleta B (2016) Revision of the genus Rhondes Simon, 1901 (Araneae: Salticidae) from New Caledonia. Insect Systematics \& Evolution 47: 15-31. https://doi. org/10.1163/1876312X-46052131

Patoleta B, Gardzińska J (2013) Redescription of Lystrocteisa Simon, 1884 (Araneae: Salticidae) from New Caledonia. Zootaxa 3646(5): 587-592. https://doi.org/10.11646/ zootaxa.3646.5.8

Prószyński J (1984) Atlas rysunków diagnostycznych mniej znanych Salticidae (Araneae). Wyższa Szkola Rolniczo-Pedagogiczna w Siedlcach 2: 1-177.

Simon E (1885) Matériaux pour server a la faune arachnologique de la Nouvelle Calédonie. Annales de la Société entomologique de Belgique 29(C.R.): 87-93. 
Simon E (1900) Descriptions d'arachnides nouveaux de la famille des Attidae. Annales de la Société Entomologique de Belgique 44: 381-407.

Simon E (1901) Histoire naturelle des araignées. Paris 2, 381-668.

Szüts T (2002) Remarks on the genus Corambis Simon, 1901 (Araneae: Salticidae). Folia Entomologica Hungarica 63: 23-31.

WSC (2017) World Spider Catalog. Natural History Museum Bern. http://wsc.nmbe.ch, version 18.0 [accessed on 28 March 2017]

Żabka M (1988) Salticidae (Araneae) of Oriental, Australian and Pacific regions, III. Annales Zoologici 41: 421-479.

Żabka M (1991) Salticidae (Arachnida: Araneae) of Oriental, Australian and Pacific Regions, VI. Mopsolodes, Abracadabrella and Pseudosynagelides - new genera from Australia. Memoirs of the Queensland Museum 30: 621-644. 